\title{
Does Spending Make Us Happy? The Role of Consumption on Life Satisfaction
}

\author{
Devrim Dumludag (corresponding author) \\ Professor \\ Department of Economics \\ Marmara University \\ Istanbul, Turkey, 34722 \\ Email: Dumludag@marmara.edu.tr \\ ORCID ID: https://orcid.org/0000-0002-4366-2317 \\ Turkey \\ Ozge Gokdemir \\ Associate Professor \\ Department of Economics \\ Istanbul University \\ Istanbul Turkey \\ Email: ozge.gokdemir@istanbul.edu.tr \\ Turkey \\ Ruut Veenhoven \\ Emeritus Professor \\ Erasmus Happiness Economics Research Organization \\ Erasmus University Rotterdam in the Netherlands \\ and \\ North-West University in South Africa \\ Optentia Research Program \\ Email: veenhoven@ese.eur.nl \\ Netherlands
}

\section{ABSTRACT}

In economic theory 'consumption' is commonly seen as final 'utility', but the factual relationship between consumption and life satisfaction has hardly been considered. Empirical research on this matter can provide a basis for more informed consumer choice. We add to the emerging literature on this matter with a survey study among the general public in Turkey.

For the degree of absolute consumption, we found a negative relationship with life satisfaction, savers being happier than spenders. For kinds of consumption, we found mostly negative correlations with life satisfaction, in particular with housing expenses. The only positive correlation with life satisfaction was expensed on eating out and vacations.

These results illustrate that the relationship between consumption and life satisfaction is more complex and variable than is commonly assumed.

\section{Keywords: consumer behavior, experienced utility, contextual variation, happiness, life satisfaction,} absolute consumption, savings.

Jel Codes: D11, D12, D14, I31

\section{INTRODUCTION}

The consumption of goods and services constitutes an essential part of our lives and constitutes the biggest share in the Gross Domestic Product of a nation. Hence it is worth knowing how consumption affects our well-being, our life satisfaction ${ }^{1}$ in particular. Economists often take for granted that a higher level of consumption means greater 'welfare' and hence greater life satisfaction, and the law of decreasing utility suggests that consumption especially contributes to the life satisfaction of the poor.

'In this paper the terms 'life-satisfaction' and 'happiness' are interchangeably used to denote the 'subjective enjoyments of one's life as a whole'. This concept is delineated in detail in Veenhoven (1984) https://ijbassnet.com/
Many scholars have provided insights into the relationship between absolute consumption and life satisfaction, typically using income as a proxy for the number of goods and services consumed. Cross-sectional studies within countries demonstrate that at any given point in time in a specific country, people with higher incomes/consumption levels are happier than people with lower incomes/consumption levels and on average, people living in rich countries are happier than those living in poor countries. These studies, by controlling a large set of socio-economic and demographic variables, have revealed that the relationship between income and happiness is statistically significant though modest in size, 


\author{
E-ISSN: 2469-6501 \\ VOL: 7, ISSUE: 10 \\ October/2021 \\ DOI: http://dx.doi.org/10.33642/ijbass.v7n10p5

e.g. Diener et. al., 1995; Inglehart, 2018, Di Tella, MacCulloch, \& Oswald, 2001; Easterlin, 1995; Frijters, Haisken-DeNew \& Shields, 2004; Frey \& Stutzer, 1999; Veenhoven, 1991; Oswald,1997; Stutzer, 2004; Diener, Sandvik, Seidlitz \& Diener, 1993 and McBride, 2001. More of this research is presented in the section 'Happiness and Income' of the World Database of Happiness (Veenhoven 2019).

On the other hand, little is known about the effects of consumption on life satisfaction. Individuals spend their disposable income on several consumption categories such as food, durables, and household items; however, we do not know which of these contributes most to our happiness, and in particular not what degree of consumption and what consumption mixes yield the most happiness for what kinds of people. This is no problem if consumers are fully informed about their needs and act rationally, yet we know that this assumption of the classic economy is not well met in reality. People can spend their income in ways that do not make them any happier. In terms of Kahneman et al (1997): 'expected' utility does not always fit later 'experienced' utility.

This paper aims to contribute to the understanding of the relationship between consumption and happiness by providing direct evidence on aggregate consumption, and kinds of consumption. This was done by using a unique survey that provided direct evidence on the relationship between happiness and consumption. The numerous studies on consumer expenses typically do not involve questions about happiness, e.g. Household Budget Survey of the Turkish Statistical Institute (TURKSTAT-TUIK), while studies on happiness do not include questions on consumption, e.g. the Turkish Quality of Life Survey. A unique survey was designed by the authors of this paper and applied by a professional research organization in 12 regions in Turkey with a total of 3008 respondents.

The paper is organized as follows: in section 2 theoretical approaches to subjective well-being are introduced. In section 3 earlier researches on the relationship between consumption and happiness are discussed and the research questions are formulated. Following, survey study and report on sampling and measurement are presented in the methodological section 4. Descriptive data on how happy the respondents are and how much they consume absolutely and what they consume are presented in section 5. Next, the relationships between happiness and the two aspects of consumption are discussed in section 6. Finally, the key results and discussions presented in section 7 and section 8 conclude.

\section{THEORETICAL APPROACHES TO THE SUBJECTIVE WELL-BEING}

Standard economic theory assumes that consumption is linked to the utility of an individual. The utility is objective and depends on goods and services and leisure. However, with the emergence of happiness economics, there is a rising interest in the concept of "subjective wellbeing" and as a result, in economic models, several scholars started using life satisfaction as a proxy for utility (Frey and Stutzer 2002).

Life satisfaction is considered as the degree to which an individual judges the overall quality of his/her life as-awhole favorably (Veenhoven 1991). Interview techniques applied in the anonymous questionnaire have allowed the quantitative measurement (cognitive assessment) of life satisfaction to evaluate individuals' feelings on a detailed Likert-type scale (Michalos, 1985). ${ }^{2}$

The question of how individuals achieve the happiness they seek in their daily life is of critical concern and for the last couple of decades, it has been attracting increased interest from several disciplines such as psychology, sociology, and economics. As a result, there is an extensive body of literature analyzing the role of subjective wellbeing to understand individuals' quality of life (Frey and Stutzer, 2002; Diener, Suh, Lucas, and Smith, 1999; Kahneman, Diener, and Schwarz, 1999).

The empirical analyses typically employ a standard micro-econometric happiness function. Individuals' reported satisfaction is regressed on a wide number of controls such as socio-demographic (e.g. age, gender, marital status) and socioeconomic (e.g. income, education, unemployment) characteristics as well as on the main variables (e.g. relative income or inflation) to be analyzed. To ease the interpretation of the results, ordered probit or least-squares estimation is frequently presented.

To examine the association between happiness and other factors, empiric studies typically employ cross-sectional and/or longitudinal analysis. Since cross-sectional data reveals the simple point-of-time association between happiness and other factors, there is a possibility that the relationship may vary over time. Researchers also use the longitudinal component of the panel data to examine the changes in wellbeing and its relation with other factors over time.

Although happiness economics' has been established since 2000, that this innovation has not yet landed in consumer research. One of the reasons is that most of the researchers use income as a proxy for consumption. This is mostly because collecting data on consumption is costlier. On the other hand, most of the household budget surveys, which employ consumption expenditures, do not include the question of happiness.

As a result, scholars are confronted with relatively few researches examining the relation between happiness and consumption, and most of these surveys provide fewer consumption variables than a typical household budget survey. Finally, existing surveys mostly include data on developed economies. There is limited information on the relation between consumption and life satisfaction in developing economies. 


\title{
International Journal of Business and Applied Social Science (IJBASS)
}

\author{
E-ISSN: 2469-6501 \\ VOL: 7, ISSUE: 10 \\ October/2021 \\ DOI: http://dx.doi.org/10.33642/ijbass.v7n10p5

\section{EARLIER RESEARCH ON CONSUMPTION AND LIFE-SATISFACTION}

Economists have generally treated income and consumption interchangeably. This is because income is easier to report and income data (although these may understate some financial resources) is available in most of the (larger) datasets. Questions about consumption expenditures are rarely asked in household surveys. The few studies that have done so are discussed below.

\subsection{Absolute Consumption and Life Satisfaction}

Considering 'absolute' consumption, we distinguish between how much people spend (total consumption) and on what (kinds of consumption). Using the US Panel Study of Income Dynamics (PSID) micro-level panel data, Brown and Gathergood (2017) found that total consumption expenditure correlates stronger with life satisfaction than income. Noll and Weick (2015) using the German Socio-Economic Panel Study (GSOEP) for 2010 (in which a module for consumption was included) showed that life satisfaction increases with increasing consumption expenditures. More such findings can be found in the section 'Happiness and Consumption' of the World Database of Happiness (Veenhoven 2019b). The results of a longitudinal analysis of Hungary, (Headey, Muffels, and Wooden, 2008) demonstrated that gains in wealth and income were positively related to changes in life satisfaction, while increased consumption was related negatively to happiness. A post hoc explanation suggested by the authors holds that people become worried if their consumption rises at a given level of income and wealth; if consumption exceeds income, then a net loss of wealth (dissaving) occurs, which is likely to reduce satisfaction.

In a study among the general public in Germany Noll and Weick (2015) found a significant correlation between life satisfaction and expenditures on clothing and leisure, while the correlation between life satisfaction and expenditures on food and housing was not significant. In a study in Japan Zhang and Xiong (2015) found that 41 out of the 77 consumption variables (monetary and nonmonetary) were significantly related to life satisfaction. Examining the association between various components of consumption expenditure and happiness, Deleire, and Kalil (2010), using the Health and Retirement Study (HRS), found that spending on leisure goods and activities such as vacations, entertainment, sports, and leisure equipment is associated with higher levels of happiness. They did not find a significant correlation between happiness and other types of consumption such as food, utilities, and health care.

Similar results have been observed in recent studies in transition countries. Dumludag (2015) using the Life in Transition Surveys (LITS) I (2006) and LITS II (2010) revealed that expenditure on seven consumption categories was significantly related to higher life satisfaction: clothing, transport and communication, entertainment, furnishings, and durable goods, while only health expenditure was not statistically significant for transition countries. The regression results also revealed that the relationship between consumption categories and life satisfaction differs at different levels of development. Using the same LITS 2 dataset, Gokdemir (2015) analyzed the relationship between consumption and life satisfaction in Turkey. She found that among the seven consumption subcategories only expenditure on durables was significantly related to life satisfaction.

Using household economic data from Britain and Hungary, Headey, Muffels, and Wooden (2008) analyzed the relationship between expenditures on nondurables (sum of expenditures on food and groceries, meals out and leisure, etc.) and happiness and observed that durable consumption expenditures also prove to be equally strongly related to happiness as income for Britain and Hungary, where consumption data are available. In a case study for seven communities in Peru, Guillen-Royo (2008) by using the Resources and Needs Questionnaire (RANQ) (a sub-sample of 254 households for the years 2004 and 2005) showed that higher expenditure is related to increased happiness while controlling for socio-demographic characteristics and levels of intermediate needs. Using HILDA (206-2010), Wu (2019) studied the relationship between happiness and several consumption types such as conspicuous and basic consumption, aggregate consumption, savings, and relative consumption in Australia. The main findings of the study revealed that conspicuous (visible and positional) spending increases life satisfaction. On the other hand, savings, spending on basic goods and services do not contribute to life satisfaction.

Some of the studies in this strand have revealed that some kinds of consumption go with less happiness. Dumludag (2015) found that education expenditures were negatively related to life satisfaction in transition countries. Gokdemir (2015) running regressions for males and females in Turkey demonstrated that expenses on durables go with greater happiness among both sexes, but that among females, expenses on clothing and footwear were negatively related to life satisfaction.

\section{METHOD}

This study aims to extend the existing literature and data by seeking answers to the following two questions: How much consumption is optimal happiness-wise? What kinds of consumption yield the most happiness?

To answer these questions a cross-sectional analysis of a general population survey (designed by the authors and administered in Turkey) is used. The survey combined explicit questions on happiness and the two aspects of consumption: how much one consumes, both 1) absolutely and 2) what one consumes. 


\author{
E-ISSN: 2469-6501 \\ VOL: 7, ISSUE: 10 \\ October/2021 \\ DOI: http://dx.doi.org/10.33642/ijbass.v7n10p5 \\ (c) 8 \\ https://creativecommons.org/licenses/by/4.0/
}

\subsection{Survey}

The survey was conducted between January 2016 and April 2016. In total a representative sample of 3,008 individuals was selected randomly for face-to-face interviews, across 12 regions in Turkey, in parallel with the Turkish Statistical Institute classification of level 2. ${ }^{3}$ All survey interviews were carried out face-to-face and door-todoor. ${ }^{4}$ Within a selected household, one respondent (who is eligible to answer for the household consumption) was surveyed. The survey took more than 30 minutes to administer due to most respondents requiring time to seek documents and make calculations of expenditure on 12 main consumption categories. The interviewer asked respondents to answer several series of general questions about household and expenses, personal characteristics, and life satisfaction. The gender of respondents was almost equally split. ${ }^{5}$

\subsection{Variables}

Three kinds of variables were used in this study: 1) consumption (independent), 2) life satisfaction (dependent), and 3) control variables, which served to weed out spurious correlation and were used to inspect possible differences in subgroups of the population.

\subsubsection{Consumption}

In this study, for representation and comparison concerns, 12 main consumption categories and 38 consumption sub-categories are included in the survey. The question for the consumption categories food, rent, and utilities was "During the past 30 days, approximately how much did your household spend on .....?". For consumption expenditures on education, durables and vacations, the time frame was 'over the past twelve months, which annual categories were then converted to monthly expenditures calculated in the local currency. As a robustness check a separate question "How much Turkish Lira did your household spend last month?" was asked as an open question. Retrospective estimates of consumer expenditures are less precise than summations made from expenditure diaries, yet not very different on average (Battistin 2003). Greater precision was not required for the research questions at hand.

In the survey, the categorization of TURKSTAT is followed for comparison purposes. Only some labels changed and rather than miscellaneous goods and services labels, two labels are used for the better view of the consumption expenditures. Therefore, in the survey, 12 main consumption categories, similar to those used in the TUIK (TURKSTAT) household budget survey (which does not include a subjective well-being question) are used (See table 1). In addition, 38 consumption sub-categories (TURKSTAT) are included in the survey. Rather than using TUIK (TURKSTAT)'s consumption category titled "miscellaneous goods and services" we derived two categories "financial expenditures" and "gifts and donations". Rather than using "clothing and footwear", the term "appearance", (which is more comprehensive) related to the appearance of the respondents is used. The term

"Entertainment and Culture" is replaced with "Experience" since the subcomponents of the category are related to more than expenditure on entertainment and culture.

\title{
TABLES
}

Table 1. Kinds of consumption: 12 expenditure categories

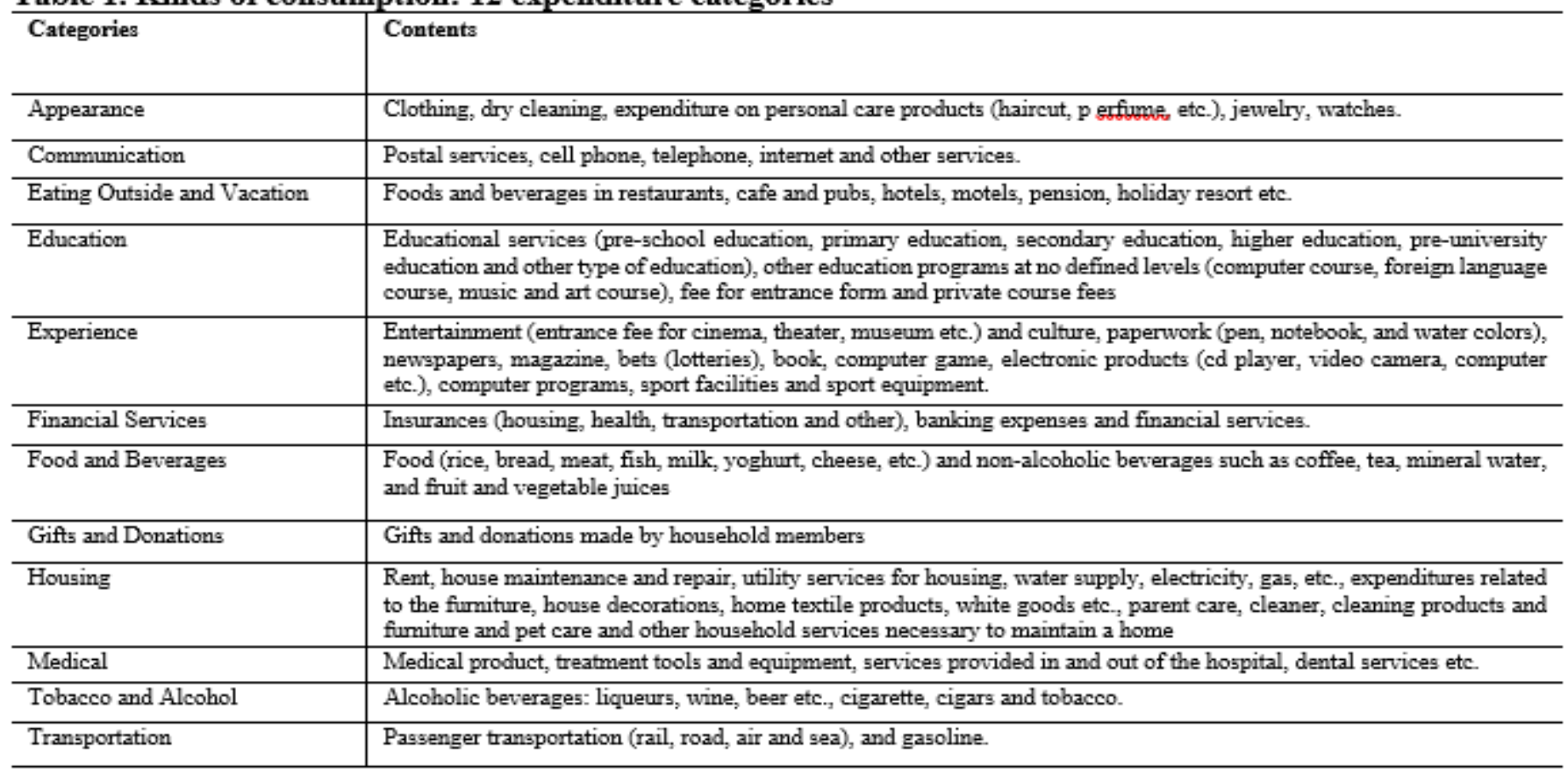




\author{
E-ISSN: 2469-6501 \\ VOL: 7, ISSUE: 10 \\ October/202 1 \\ DOI: http://dx.doi.org/10.33642/ijbass.v7n10p5 \\ (c) (7) \\ https://creativecommons.org/licenses/by/4.0/
}

\subsubsection{Life satisfaction}

The dependent variable used in this study was the subjective enjoyment of one's life as a whole, which is called 'happiness' or 'life satisfaction. This concept is delineated in more detail in Veenhoven (1984). The life satisfaction variable is measured by using responses to the following question: "All things considered, how satisfied or dissatisfied are you with your life as a whole, these days?" The answer options were graded from 0 to 10 , where 0 indicates "completely dissatisfied" and 10 is "completely satisfied".

\subsubsection{Background variables}

The following background variables are included in the analysis: a) the Big Five personality traits (Gosling, Rentfrow, \& Swann Jr, 2003), b) socio-demographic variables: gender, age, age squared, and household size, marital status, number of children, education, and c) the socio-economic variables employment and, price levels, and d) region controls.

\section{DESCRIPTIVES}

\subsection{Consumption}

Total household consumption was calculated from estimated expenses in 12 consumption categories and ranged between 500 and 12000 Turkish Lira per month, with an average of 2,224 and a standard deviation of 1.097. The average of estimates given on the monthly and annual consumption expenditures was 2,648 with a standard deviation of 1,339. Estimates of average household consumption in Turkey in 2015 and 2016 based on a budget survey of TURKSTAT are 1,455 and $1,642 .{ }^{6} 18 \%$ of the respondents reported having saved money in the last month.

A key comparative advantage of the survey was that its consumption categories were designed to parallel those of the Turkish Statistical Institute Household Budget Data. ${ }^{7}$ Both surveys are designed to obtain direct information on the twelve consumption categories shown in Table 2 and the shares of these categories were remarkably similar for most of the items.

Table 2. Expenditures on kinds of consumption as a percentage of total household consumption expenditures for full survey sample in comparison with estimate by Turkish Statistical Institute, (TURKSTAT -TUIK)

\begin{tabular}{ll|l}
\hline Consumption Categories in \% & Our Sample & TUIK(2015) \\
\hline Food and non-alcoholic beverages & & \\
Alcoholic beverages, cigarette and tobacco & 21.24 & 20.2 \\
Clothing and footwear & 6.46 & 4.17 \\
Housing and rent & 4.25 & 5.19 \\
Furniture, houses appliances and home care services & 25.54 & 26.04 \\
Health & 7.98 & 6.14 \\
Transportation & 1.10 & 2 \\
Communication & 9.01 & 16.97 \\
Entertainment and culture & 5.25 & 3.65 \\
Educational services & 6.12 & 2.87 \\
Restaurant and hotels & 2.34 & 2.17 \\
Various good and services & 6.82 & 6.35 \\
\hline
\end{tabular}

In both surveys, housing and rent expenditure, and food and non-alcoholic beverages expenditure constituted close to half of the total consumption expenditures of a respondent. In both surveys, the third biggest category of expenditure was transportation; the share of transportation was much smaller in this survey in comparison to TUIK/TURKSTAT data. The other significant difference was expenditure on entertainment and culture: in the survey, the share of entertainment expenditures was 6.12 whereas its share was 2.87 in the TUIK/TURKSTAT data. Education had a small percentage of consumption because a significant number of respondents (elderly couples, adults with no children, etc.) declared zero consumption for education.

\subsection{Life-satisfaction}

In the survey average life satisfaction on a scale, $0-10$ was 6,03 and the standard deviation was 2,83 . This was higher than the mean of 5,58 observed in the 2010 LITS study (Gokdemir 2015) and also higher than the 5.40 mean observed in the Turkish Eurobarometer survey in 2016 as transformed from a 4-step verbal response scale in the World Database of Happiness (Veenhoven 2019)

\subsection{Background variables}

Means and standard deviations of socio-economic, socio-demographic, and financial variables are presented in the Appendix.

\section{ANALYSIS}

Here, two questions are examined: "How much consumption is optimal happiness-wise? and "What kinds of consumption yield the most happiness?" 
To answer these questions, first, univariate analysis is applied, and then a multi-variate analysis using ordinary least squares (OLS) regressions, treating life satisfaction as a cardinal construct is conducted. The results of cardinal models are more intuitive and easier to interpret than estimates obtained using ordinal probit models. In addition, cardinal and ordinal analyses of life satisfaction have been shown to yield similar results (Ferrer-i-Carbonell and Frijters, 2004). ${ }^{8}$

\subsection{Degree of consumption}

A plot of happiness against a) consumption and b) income is presented in Figure 1. Unsurprisingly, a higher household income goes together with greater happiness in Turkey, but surprisingly, more consumption does not. Taking a closer look we saw that low-income respondents are happier when they spend more than they earn, while at the higher income levels respondents tend to be happier if they spend less than they earn. A positive relationship between saving and happiness in Turkey is observed, as visualized in Figure 2.

Figure 1. Household Income, Aggregate consumption and Happiness in Turkey

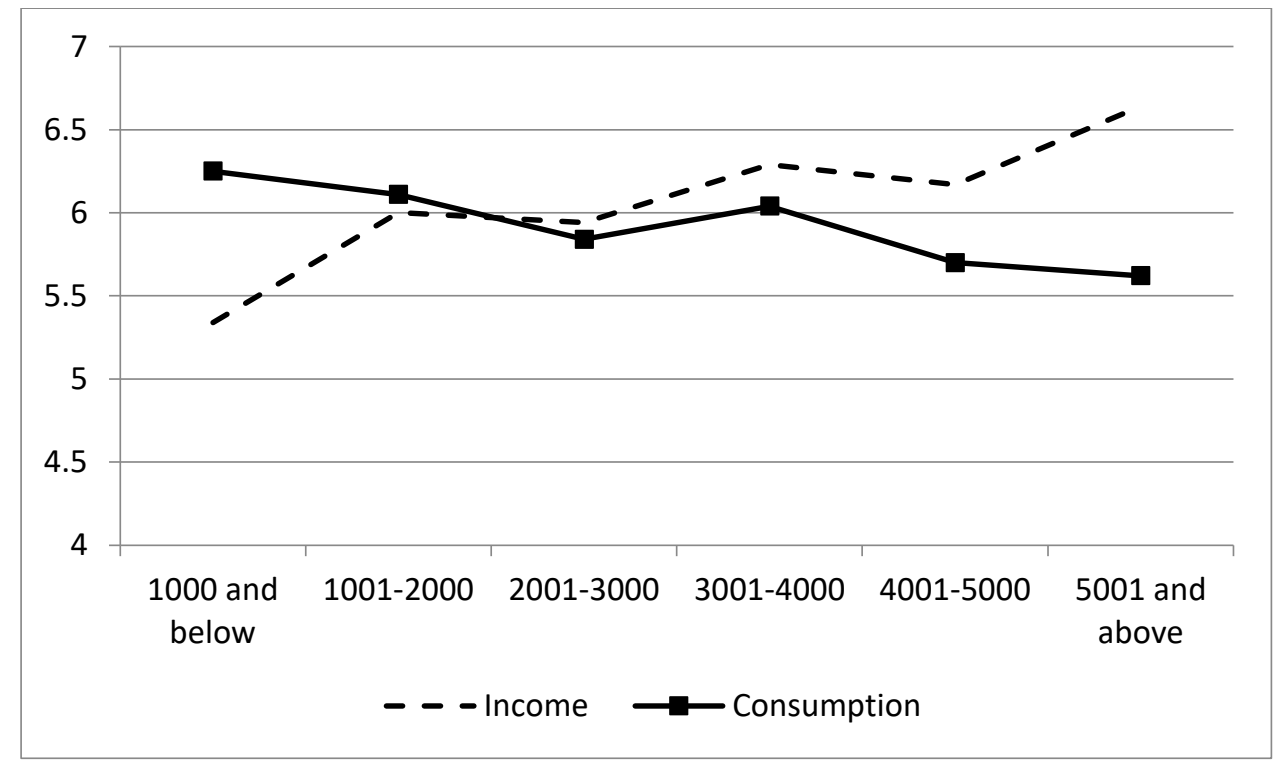

Figure 2. Annual Savings and Life Satisfaction in Turkey

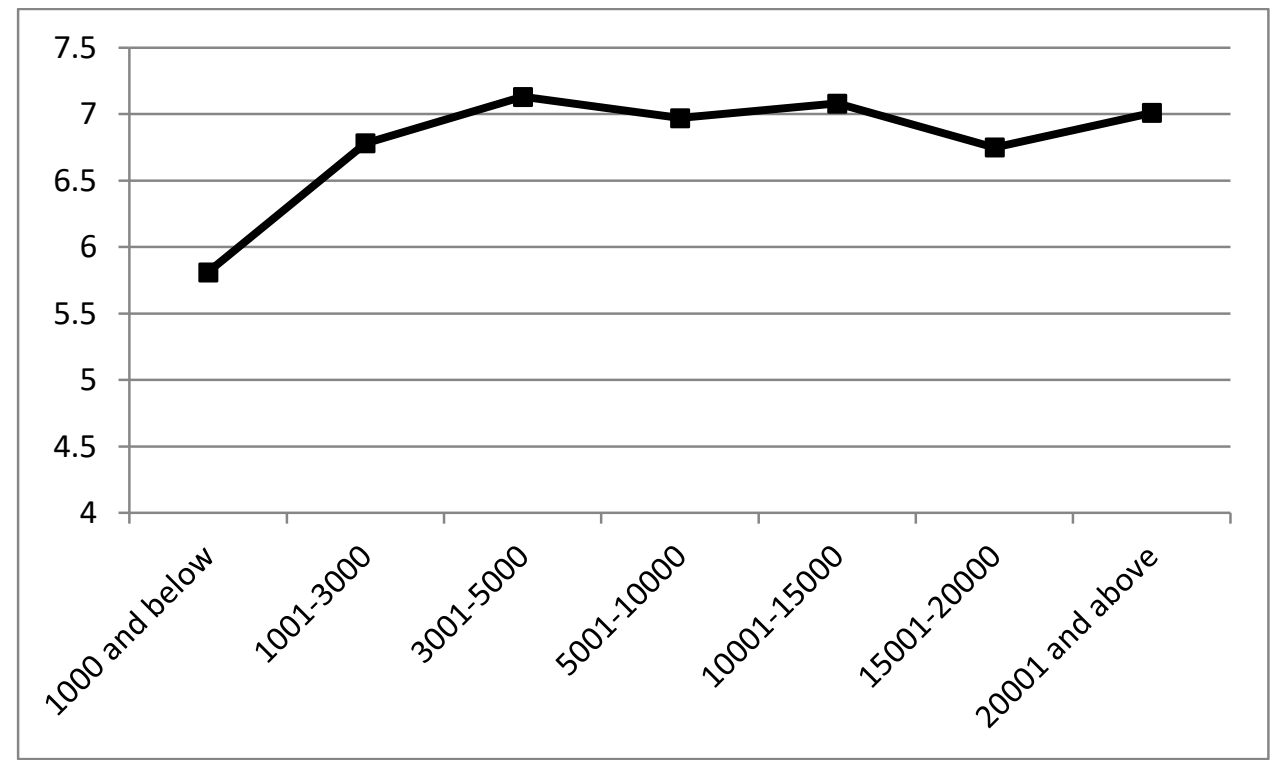




\author{
E-ISSN: 2469-6501 \\ VOL: 7, ISSUE: 10 \\ October/2021 \\ DOI: http://dx.doi.org/10.33642/ijbass.v7n10p5 \\ (c) (†) \\ https://creativecommons.org/licenses/by/4.0/
}

Life satisfaction score rises substantially from 5.81 for savings of 1,000 and below the level to 7.13 for 3000 to 5,000 Turkish Lira saved and then remains about at the same level for higher rates of monthly savings. No clear pattern of diminishing happiness returns of saving was seen in these data. The results of the multivariate analysis are presented in table 3 .
The regression results suggest that an increase in aggregate consumption harmed life satisfaction and it is found that household income and savings had a positive relationship with life satisfaction, which was statistically significant. Likewise, see in table 4 that life satisfaction also relates negatively to most of the expenditure on specific kinds of consumption.

Table 3. Life-satisfaction by income, consumption and saving -OLS Estimates for Coefficients Full Sample

\begin{tabular}{|c|c|c|c|c|c|}
\hline Dependent variable & (1) & (2) & (3) & (4) & (5) \\
\hline & Estimated & Estimated & Estimated & Estimated & Estimated \\
\hline Life satisfaction $(0-10)$ & $\begin{array}{l}\text { Coefficient } \\
\text { (Std. Error) }\end{array}$ & $\begin{array}{l}\text { Coefficient } \\
\text { (Std. Error) }\end{array}$ & $\begin{array}{l}\text { Coefficient } \\
\text { (Std. Error) }\end{array}$ & $\begin{array}{l}\text { Coefficient } \\
\text { (Std. Error) }\end{array}$ & $\begin{array}{l}\text { Coefficient } \\
\text { (Std. Error) }\end{array}$ \\
\hline Ln monthly household income & $\begin{array}{l}1.096^{* 88} \\
(0.311)\end{array}$ & $\begin{array}{l}0.563^{* 8} \\
(0.223)\end{array}$ & - & - & $\begin{array}{l}0.040 \\
(0.156)\end{array}$ \\
\hline $\begin{array}{l}\text { Ln monthly household } \\
\text { consumption (declared) }\end{array}$ & $\begin{array}{l}-1.202^{* 8 *} \\
(0.326)\end{array}$ & - & $\begin{array}{l}-0.280^{*} \\
(0.152)\end{array}$ & - & - \\
\hline $\begin{array}{l}\text { Ln monthly household } \\
\text { consumption (calculated) }\end{array}$ & - & $\begin{array}{l}-0.654^{* * 8} \\
(0.226)\end{array}$ & - & $\begin{array}{l}-0.348^{* *} \\
(0.144)\end{array}$ & - \\
\hline Savings & - & - & $\begin{array}{l}0.179^{8 * 8} \\
(0.025)\end{array}$ & $\begin{array}{l}0.182^{* 88} \\
(0.025)\end{array}$ & $\begin{array}{l}0.165^{* 88} \\
(0.030)\end{array}$ \\
\hline Observations & 3006 & 3006 & 3006 & 3006 & 3006 \\
\hline Adjusted R-squared & 0.116 & 0.115 & 0.091 & 0.092 & 0.090 \\
\hline
\end{tabular}

Note: ${ }^{* * *}=p<0.01,{ }^{* *}=p<0.05,{ }^{*}=p<0.10$.

Controls for model 1-2:age, age ${ }^{2}$, education gender, number of children, household size, single, separated and divorced, widowed, married (ref), unemployed, housewife, retired, student, employed (ref), car ownership, room number, residence ownership, borrowed, spend savings, saved money, neither borrowed nor saved (ref), region price, region dummies, personal characteristics (big 5) (Controls for the model 3-4-5 are same except, borrowed, spend savings, saved money, neither borrowed nor saved (ref)]

The regression analysis presented in table 3 involved 5 steps. First, a model including only monthly household income and monthly household consumption is estimated. As expected, income was positively related to life satisfaction while; monthly household consumption (declared by the respondents) related negatively to life satisfaction. In the second step, an alternative "monthly household consumption" as the sum of the consumption categories is computed. Once more, the result that monthly consumption (calculated) was negatively related to life satisfaction is found, but the impact was a bit lower than the declared overall consumption expenditure. In the third step savings variable is introduced. The aim was to see whether there is a relation between savings and subjective well-being, since saving money can reduce financial stress. . From the results it can be seen that saving money goes with greater life satisfaction.
However, the coefficient of household consumption was smaller than in the first and second models when income and savings were not included in the third step. The negative correlation between consumptive expenditures and life satisfaction is more sizable than the positive correlation between savings and life satisfaction. When, in model 5, declared overall consumption expenditure is changed to a calculated consumption, the same pattern is observed. Finally, A model is estimated that included monthly household income and savings. The results showed that only savings were positively correlated with life satisfaction.

\subsection{Kinds of consumption}

The second research question was which kinds of consumption add most or least to life satisfaction. In its most basic form, the baseline cross-section model we employed for life satisfaction is specified as follows:

$$
S_{i}=X_{i} \beta+\sum \gamma C_{i j}+e_{i}
$$


Where $S_{i}$ equals the level of life satisfaction of the Survey classification. The results showed that not all these respondent I; $X_{i}$ represent the controls; $\boldsymbol{C} i j$ is consumption expenditure in consumption category " $\mathrm{j}$," the Greek symbols indicate parameters; and $e_{i}$ is an idiosyncratic error. In the current study 12 consumption categories are kinds of consumption were statistically significantly related to life satisfaction. Moreover, expenses on some consumption items were seen to go with less happiness among out Turkish respondents. distinguished, in parallel with TUIK's Household Budget

Table 4. Life-satisfaction by expenditures on specific kinds of consumption- OLS estimates for full sample and males and gender sub-categories

\begin{tabular}{|c|c|c|c|c|c|c|}
\hline & All & & Females & & Males & \\
\hline Dependent variable: & Estimated & Standard & Estimated & Standard & Estimated & Standard \\
\hline Life satisfaction $(0-10)$ & Coefficient & Error & coefficient & Error & coefficient & error \\
\hline Ln Appearance & -0.066 & 0.079 & 0.006 & 0.113 & -0.068 & 0.110 \\
\hline Ln Communication & 0.102 & 0.105 & 0.206 & 0.150 & 0.020 & 0.139 \\
\hline Ln Tobacco & $-0.047^{* 8}$ & 0.020 & -0.030 & 0.027 & $-0.068 * 8$ & 0.031 \\
\hline Ln Eating outside and vacation & $0.070 * *$ & 0.032 & 0.046 & 0.044 & 0.071 & 0.048 \\
\hline Ln Education & $-0.054^{* 8}$ & 0.026 & -0.052 & 0.036 & -0.050 & 0.037 \\
\hline Ln Experience & -0.038 & 0.031 & -0.010 & 0.045 & $-0.074 *$ & 0.044 \\
\hline Ln Food & $-0.195 *$ & 0.114 & -0.152 & 0.151 & -0.220 & 0.171 \\
\hline Ln Gifts and Donations & -0.024 & 0.032 & -0.036 & 0.044 & -0.010 & 0.046 \\
\hline Ln Housing & $-0.306^{* 8}$ & 0.138 & -0.097 & 0.165 & -0.523 & 0.209 \\
\hline Ln Medical & 0.014 & 0.037 & -0.002 & 0.049 & -0.009 & 0.056 \\
\hline Ln Financial & $-0.084 * 8 *$ & 0.025 & -0.048 & 0.036 & $-0.109 * 8 *$ & 0.036 \\
\hline Ln Transport & -0.035 & 0.042 & -0.066 & 0.053 & -0.044 & 0.067 \\
\hline Observations & 3006 & & 1498 & & 1508 & \\
\hline Adjusted R-squared & 0.120 & & 0.118 & & 0.160 & \\
\hline
\end{tabular}

Note: ${ }^{* * *}=p<0.01,{ }^{* *}=p<0.05, *=p<0.10$

Controls: age, age', education, gender (for the first model), number of children, household size, single, separated and divorce.., widowed, married (ref), unemployed, housewife, retired, student, employed (ref), car ownership, room number, residence ownership, borrowed, sped savings, saved money, neither borrowed nor saved (ref), region price, region dummies, personal characteristics (big 5), hougehold income (Note: For females and males gender is not included)

In regression 1 (full sample) expenditures on food and housing A split into three age categories reduced the number of stand out as the most negatively related to life satisfaction. statically significant correlations but did not change the effect Note that income is controlled, so this is not a matter of sizes very much. The observed strongest negative correlation poverty. The only significant positive association found was of expenses on housing appeared to be most pronounced with eating out and vacationing. The size of this association is among those aged 30 to 44 years. The negative relationship small, which suggests that the evident benefits of leisure life a with expenses on tobacco was strongest among those aged 18 balanced in some way. Among females, none of the kinds of to 29 and the positive correlation with eating out and consumption we considered were significantly related to life vacationing was also most pronounced in this age category. satisfaction. Among males, expenses on tobacco, experiences, The negative correlation with expenses on financial services is and financial services went together with less life satisfaction. more pronounced among the $45+$ aged. 


\author{
E-ISSN: 2469-6501 \\ VOL: 7, ISSUE: 10 \\ October/2021 \\ DOI: http://dx.doi.org/10.33642/ijbass.v7n10p5 \\ (c) (i) \\ https://creativecommons.org/licenses/by/4.0/
}

Table 5. Life-satisfaction by expenditures on specific kinds of consumption- OLS estimates in age categories

\begin{tabular}{|c|c|c|c|c|c|c|}
\hline & $18-29$ & & $30-44$ & & $45+$ & \\
\hline Dependent variable: & Estimated & Standard & Estimated & Standard & Estimated & Standard \\
\hline Life satisfaction $(0-10)$ & Coefficient & Error & Coefficient & Error & coefficient & error \\
\hline Ln Appearance & 0.019 & 0.118 & -0.164 & 0.158 & 0.033 & 0.138 \\
\hline Ln Communication & 0.056 & 0.180 & 0.287 & 0.176 & 0.027 & 0.198 \\
\hline Ln Tobacco & $-0.112 * 8 *$ & 0.036 & $-0.069 *$ & 0.037 & 0.034 & 0.035 \\
\hline Ln Eating outside and vacation & $0.112 *$ & 0.061 & 0.080 & 0.057 & 0.036 & 0.053 \\
\hline Ln Education & -0.06 & 0.047 & -0.043 & 0.044 & -0.072 & 0.048 \\
\hline Ln Experience & -0.070 & 0.061 & -0.057 & 0.061 & -0.043 & 0.051 \\
\hline Ln Food & -0.132 & 0.169 & -0.131 & 0.248 & -0.366 & 0.235 \\
\hline Ln Gifts and Donations & -0.075 & 0.058 & 0.040 & 0.056 & -0.049 & 0.056 \\
\hline Ln Housing & -0.271 & 0.209 & $-0.495^{*}$ & 0.288 & -0.158 & 0.251 \\
\hline Ln Medical & -0.012 & 0.065 & 0.055 & 0.065 & 0.019 & 0.067 \\
\hline Ln Financial & $-0.098 * 8$ & 0.046 & -0.034 & 0.045 & $-0.120 * 8$ & 0.048 \\
\hline Ln Transport & -0.004 & 0.085 & 0.012 & 0.072 & -0.091 & 0.067 \\
\hline Observations & 942 & & 980 & & 1084 & \\
\hline Adjusted R-squared & 0.122 & & 0.122 & & 0.116 & \\
\hline
\end{tabular}

Note: ${ }^{* * *}=p<0.01,{ }^{* *}=p<0.05, *=p<0.10$.

Controls: education, gender, number of children, household size, single, separated and divorced, widowed, married (ref), unem,loyed, housewife, retired, student, employed (ref), car ownership, room number, residence ownership, borrowed, sped gavings, saved money, neither borrowed nor saved (ref), region price, region dummies, personal characteristics (big 5), household income

\section{DISCUSSION}

\subsection{Findings on the degree of consumption}

The first research question was how

much consumption is optimal for happiness. Looking at the absolute level of consumption, a negative correlation with life satisfaction was found. Since income was controlled, this means that the respondents tended to be less happy with the more disposable income they consumed. One possible explanation is that saving adds more to happiness than spending, at least in Turkey, which fits an earlier observation by Dumludag (2015) in another sample in this country. Another explanation is that happiness reduces consumption, since happy people can more easily do without, or conversely, that unhappiness may foster consumption, possibly as a way to feel better. Note: the first explanation does not exclude the second; both may be in play.

The finding that more consumption does not go with greater happiness in Turkey contradicts the commonly held view in economics that consumption marks final utility. The findings also show that social comparison is a less universal tendency than has been assumed based on studies done in developed economies. This is another blow to the Easterlin
Paradox (1974) for which the now available data show that it describes the exceptions rather than the rule (e.g. Veenhoven \& Vergunst 2014).

\subsection{Findings on kinds of consumption}

In line with the above reported negative relation between life-satisfaction and total consumption, negative correlations between life-satisfaction and most consumption categories were found. The negative correlations differed in size, and the most negative correlations with life satisfaction were found for expenditure on food and housing. One possible explanation is that prioritizing these necessities goes at the cost of more satisfying ways of spending one's disposable income. Another explanation could be that unhappiness fosters spending on these basics in some ways, such as by seeking security.

The main surprise was that the only significant positive correlation was for expenditure on eating out and vacations. The use of the many control variables makes a spurious correlation improbable. One possible causal explanation is that buying pleasurable experiences enhances one's life satisfaction, even when this goes at the cost of savings. Another explanation could be that happiness fosters a 


\author{
E-ISSN: 2469-6501 \\ VOL: 7, ISSUE: 10 \\ October/202 1 \\ DOI: http://dx.doi.org/10.33642/ijbass.v7n10p5

preference for pleasurable social activities, while unhappiness fosters expenditure on things rather than experiences. Again, both effects can work independently in concert.

\subsection{Limitations}

Measurement: Consumption is measured by using retrospective estimates of expenditure in the last month. These estimates are less precise than calculations made from expenditure diaries or bank statements and can be biased by self-defensive denial, e.g. underreport of expenditure on alcohol. As argued above in section 3.2.1, this imprecision is not a great problem for this study on the effects of more or less, though it may have reduced the size of the observed correlations. Desirability bias may have involved underreporting of some kinds of expenditures and such bias could correlate with over-optimistic ratings of life satisfaction, however, this has not veiled a negative correlation between consumption and life satisfaction, but may at best have reduced the negative correlation somewhat.

Causality: As seen above, the cross-sectional data used here cannot be used to inform the reader about the direction of causality behind the observed statistical relationships. The causal mechanisms suggested sound plausible, but to support these ideas, an empirical check should be carried out for which a need for longitudinal data that allow scholars to do a fixed-effect analysis. Laboratory experiments would be almost impossible for major consumer goods, but it is possible to learn from natural experiments and case studies such as looking at effects of inherited goods, status goods, or financial services that become publicly available (e.g. Frank, 2000; Frey, 2018). The data also fall short concerning specification across subgroups. The sample was too small to split further than across age and gender and the other background variables are used as controls. Pooling the data with new survey data that include answers to the same questions would solve this problem.

Controls: The last limitation is in the controls used in this analysis. The common practice in econometric analysis, controlling many background variables that are related to life satisfaction might create a spurious correlation. These variables are specified at the bottom of table 4. Yet this practice involves the risk of over-control and subsequent underestimation of the relationship between consumption and life satisfaction. For instance, in the case of expenditure on housing, control for married status may prevent us from seeing that the correlation with life satisfaction is boosted by the fact that married people tend to dwell in bigger houses and that being married makes them happier. A cheap cramped dwelling may reduce the chance that you will get married or that your marriage will survive. Such problems cannot be solved using the cross-sectional design of the study presented here, what we will require is a fixed effect analysis of follow-up data.

\section{CONCLUSIONS}

The relationship between consumption and life satisfaction appears to be more complicated than commonly assumed. Empirical research shows different correlations across and within countries, which are open to different interpretations. In this case of contemporary Turkey, more consumption goes together with less life satisfaction. In Turkey, the only kind of consumption that goes with greater happiness is spending on eating out and vacations. This contextual variation implies that empirical happiness research will not produce universal recommendations for ways of consumption that add to a more satisfying life. Evidence-based consumption-counseling will require constant monitoring of the effects of consumption among different people and contexts.

\section{ACKNOWLEDGEMENT}

The field survey of the project is funded by the Scientific Research Unit of Marmara University, project no: SOS-1006-015-294. The material in the manuscript will not infringe upon any statutory copyright. The field survey is a unique and ethical committee of the scientific research unit at Marmara University approved the questions in the survey. A professional research company carried the field survey. The data is stored at the Department of Economics in a good condition.

\title{
REFERENCES
}

Battistin, E. (2003): Errors in survey reports of consumption expenditures, IFS Working Papers, No. 03/07, Institute for Fiscal Studies (IFS), London, http://dx.doi.org/10.1920/wp.ifs.2003.0307

Brown, Gordon D. A. and Gathergood, John, Consumption and Life Satisfaction: A Micro Panel Data Study (May 3, 2017). Available at SSRN: https://ssrn.com/abstract=2962837 or http://dx.doi.org/10.2139/ssrn.2962837

Browning M, Crossley TF, Weber G (2003) Asking consumption questions in general purpose surveys. Economic Journal 113(November):540-567

DeLeire T, Kalil A (2010) Does consumption buy happiness? Evidence from the United States. International Review of Economics 57(2): 163-176

Di Tella, R., MacCulloch, R. J., \& Oswald, A. J. (2001). Preferences over inflation and unemployment: Evidence from surveys of happiness. The American economic review, 91(1), 335-341.

Diener, E. D., Emmons, R. A., Larsen, R. J., \& Griffin, S. (1985). The Satisfaction With Life Scale. Journal of Personality Assessment, 49(1), 71-75. 


\author{
E-ISSN: 2469-6501 \\ VOL: 7, ISSUE: 10 \\ October/2021 \\ DOI: http://dx.doi.org/10.33642/ijbass.v7n10p5 \\ (c) $)$ \\ https://creativecommons.org/licenses/by/4.0/
}

CPER

Diener, E., Sandvik, E., Seidlitz, L., \& Diener, M. (1993). The relationship between income and subjective well-being: Relative or absolute? Social Indicators Research, 28(3), 195-223.

Diener, E., Suh, E.M., Lucas, R. E. \& Smith, H.L. (1999) Subjective well-being: Three decades of progress. Psychological bulletin, 125(2), 276.

Dumludag, D. (2015). Consumption and life satisfaction at different levels of economic development. International Review of Economics, 62(2), 163-182.

Easterlin, R. A. (1974). Does economic growth improve the human lot? Some empirical evidence. Nations and households in economic growth, Academic Press, 89-125.

Easterlin, R. A. (1995). Will raising the incomes of all increase the happiness of all? Journal of Economic Behavior \& Organization, 27(1), 35-47.

Ferrer-i-Carbonell, A., \& Frijters, P. (2004). How important is methodology for the estimates of the determinants of happiness? The Economic Journal, 114(497), 641-659.

Frank, R. H. (2000). Luxury fever: Money and happiness in an era of excess. Princeton University Press.

Frey, B. S., \& Stutzer, A. (1999). Measuring preferences by subjective well-being. Journal of Institutional and Theoretical Economics (JITE)/Zeitschrift für die gesamte Staatswissenschaft, 755-778.

Frey, B. S., \& Stutzer, A. (2002). What can economists learn from happiness research?. Journal of Economic Literature, 40(2), 402-435.

Frey, B. (2018). Economics of Happiness. Springer International Publishing.

Frijters, P., Haisken-DeNew, J. P., \& Shields, M. A. (2004). Money does matter! Evidence from increasing real income and life satisfaction in East Germany following reunification. The American Economic Review, 94(3), 730-740.

Gokdemir, O. (2015). Consumption, savings and life satisfaction: the Turkish case. International Review of Economics, 62(2), 183-196.

Gosling, S. D., Rentfrow, P. J., \& Swann Jr, W. B. (2003). A very brief measure of the Big-Five personality domains. Journal of Research in personality, 37(6), 504-528.

Guillen-Royo M (2008) Consumption and subjective wellbeing: exploring basic needs, social comparison, social integration and hedonism in Peru. Social Indicators Research 89(3):535-555

Headey B, Muffels R, Wooden M (2008) Money does not buy happiness: or does it? A reassessment based on the combined effects of wealth, income and consumption. Social Indicators Research 87(1):65-82

Inglehart, R. (2018). Culture shift in advanced industrial society. Princeton University Press.

Kahneman, D, Wakker, P.P \& Sarin, R. (1997) Back to Bentham? Explorations of Experienced Utility, The Quarterly Journal of Economics, 112 (2) 375-406,

Kahneman, D., Diener, E., \& Schwarz, N. (eds.) (1999) Well-being: Foundations of hedonic psychology. Russell Sage Foundation.

McBride, M. (2001). Relative-income effects on subjective well-being in the cross-section. Journal of Economic Behavior \& Organization, 45(3), 251-278.

Michalos, A. C. (1985) Multiple discrepancies theory (MDT), Social Indicators Research, 16(4), 347-413

Noll, H. H., \& Weick, S. (2015). Consumption expenditures and subjective well-being: empirical evidence from Germany. International Review of Economics, 62(2), 101-119.

Oswald, A. J. (1997). Happiness and economic performance. The Economic Journal, 107(445), 1815-1831.

TURKSTAT, Household Consumption Bulletin, 2016 http://www.tuik.gov.tr/PreHaberBultenleri.do;jsessionid=Q0mChCXbYxrm4Dkyy6Ph1QhyRpKJ1jRLzLyGYK2GQp2 JBk6RSJkk!768452478?id=24576

Turkish Statistical Institute (2018) http://www.tuik.gov.tr/MicroVeri/HBA_TH_13-14-15/english/meta-data/index.html

Wu, F. (2019). An Examination of the Effects of Consumption Expenditures on Life Satisfaction in Australia, Journal of Happiness Studies, 11-37.

Veenhoven, R. (1984) Conditions of happiness, Reidel (Now Springer), Dordrecht, Netherlands

Veenhoven, r. (2019), Happiness in Turkey, World Database of Happiness, Erasmus University Rotterdam. Available at: https://worlddatabaseofhappiness.eur.nl/hap_nat/nat_fp.php?cntry=39\&name=Turkey\&mode=3\&subjects=150\&publics=10 
DOI: http://dx.doi.org/10.33642/ijbass.v7n10p5

Veenhoven, R. (1984). Conditions of Happiness (D. Reidel, Dordrecht, Holland).

Veenhoven, R. (1991). Questions on happiness: Classical topics, modern answers, blind spots. In F. Strack, M. Argyle, \& N. Schwarz (Eds.), International series in experimental social psychology, Vol. 21. Subjective well-being: An interdisciplinary perspective (pp. 7-26). Elmsford, NY, US: Pergamon Press.

Veenhoven, R. (2019a) Happiness and Income. World Database of Happiness, Collection of Correlational Findings, Available at: https://worlddatabaseofhappiness.eur.nl/hap_cor/desc_topic.php?tid=1726

Veenhoven, R. (2019b) Happiness and consumption: Absolute consumption. World Database of happiness, Collection of Correlational Findings. Available at: https://worlddatabaseofhappiness.eur.nl/hap_cor/desc_sub.php?sid=6393

Veenhoven, R. R., \& Vergunst, F. (2014). The Easterlin illusion: economic growth does go with greater happiness. International Journal of Happiness and Development, 1(4), 311-343.

Zhang, J., \& Xiong, Y. (2015). Effects of multifaceted consumption on happiness in life: a case study in Japan based on an integrated approach. International Review of Economics, 62(2), 143-162.

\section{Appendix}

Table A1.Basic Descriptive of Socioeconomic and Sociodemographic Variables

\begin{tabular}{|c|c|c|c|}
\hline & Mean & St. Dev. & Min-Max \\
\hline $\begin{array}{l}\text { Life Satisfaction } \\
\text { Sociodemographic } \\
\text { and Socioeconomic Variables }\end{array}$ & 6,03 & 2,826 & $0-10$ \\
\hline Age & 38,87 & 14,023 & $18-87$ \\
\hline Education & 3,61 & 1,340 & $1-6$ \\
\hline Gender & 0,50 & 0,500 & $0-1$ \\
\hline Number of children & 1,48 & 1,485 & $0-11$ \\
\hline Household size & 3,73 & 1,460 & $1-13$ \\
\hline Household Income* & 2614,23 & 1801,728 & $500-20000$ \\
\hline Household Consumption* & 2224,72 & 1079,177 & $500-12000$ \\
\hline Household Savings** & 0,84 & 2,017 & $0-8$ \\
\hline \multicolumn{4}{|l|}{ Marital Status } \\
\hline Single & 0,32 & 0,465 & $0-1$ \\
\hline Widowed & 0,04 & 0,196 & $0-1$ \\
\hline Divorced & 0,03 & 0,159 & $0-1$ \\
\hline Live separate & 0,00 & 0,041 & $0-1$ \\
\hline \multicolumn{4}{|l|}{ Employment Status } \\
\hline Unemployed & 0,02 & 0,156 & $0-1$ \\
\hline Housewife & 0,22 & 0,416 & $0-1$ \\
\hline Retired & 0,11 & 0,311 & $0-1$ \\
\hline Student & 0,10 & 0,300 & $0-1$ \\
\hline Employed & 0,54 & 0,498 & $0-1$ \\
\hline Car ownership & 0,27 & 0,444 & $0-1$ \\
\hline Room number & 3,52 & 0,719 & $1-10$ \\
\hline Residence ownership & 0,56 & 0,496 & $0-1$ \\
\hline \multicolumn{4}{|l|}{ Financial Situation } \\
\hline Borrowed & 0,26 & 0,440 & $0-1$ \\
\hline Spend savings & 0,12 & 0,328 & $0-1$ \\
\hline Saved Money & 0,18 & 0,383 & $0-1$ \\
\hline Neither borrowed nor saved & 0,44 & 0,496 & $0-1$ \\
\hline
\end{tabular}

